\title{
DEBATE:
}

\section{LA MUJER EN LA GUERRA CIVIL ESPAÑOLA}

En las páginas que siguen se recoge un debate sobre el libro La mujer en la guerra civil española de Carmen Alcalde. María José Aubet, Lidia Falcón, Marina Subirats y Laura Tremosa comentan desde diversas ópticas los aspectos más relevantes del libro. Carmen Alcalde responde a estos comentarios. 


\section{PRESENTACIÓN}

La bistoria de la participación de la mujer en las luchas sociales es una bistoria que, consciente o inconscientemente, ba sido olvidada, tanto por quienes detentan el poder como por aquellos que participaron en ellas. Por ello, recuperar esa bistoria es una de las tareas importantes del movimiento feminista.

El libro La mujer en la guerra civil española de Carmen Alcalde es un intento en este sentido. El debate sobre él incluye dos comentarios que aparecieron en las revistas Materiales $y$ Vindicación Feminista bace más de un año y que incluimos por considerarlos aún de actualidad.

María José Aubet nos babia señalado que consideraba que su comentario habia sido becho como una primera respuesta al libro, ya que le babían extrañado las distorsiones sobre el pensamiento y la acción de Rosa $\mathrm{Lu}$ xemburg. Que en ese momento no babía intentado bacer un análisis más completo sobre el libro en su conjunto. En este sentido el articulo babria perdido interés actualmente. Sin embargo, a nuestro entender el artículo entrega una información valiosa sobre Rosa Luxemburg al mismo tiempo que cuestiona el método de análisis bistórico que emplea Carmen Alcalde que la lleva a recoger información parcial, por lo menos, en este caso concreto. Por ello lo incluimos.

A pesar de los problemas que señalan las distintas comentaristas, creemos que La mujer en la guerra civil española es un aporte al estudio bistórico de la mujer. 